\title{
Globalization and Paradigm Changes in Teacher Education: Revolutionizing Teaching Learning Process at School Level in Pakistan
}

\author{
Muhammad Iqbal \\ Assistant Professor, University of Education, Lahore, Pakistan \\ Tel: 92-033-3445-8038Ｅ-mail:dr97pk@yahoo.com \\ Muhammad Irfan Arif \\ Ph.D Scholar (Education), University of Education, Lahore, Pakistan \\ Tel: 92-033-3890-1810Ｅ-mail: irfanarif@yahoo.com
}

Received: June 24, 2011 Accepted: July 18, 2011 Published: November 1, 2011

doi:10.5539/ies.v4n4p99 URL: http://dx.doi.org/10.5539/ies.v4n4p99

\begin{abstract}
The world has become a global village. No county can live in isolation without seeking impact of global trends and a change in all field of life education is the most important tool in national development. So this age of knowledge has great impact on education. Teacher education is the brain of all educational disciplines as it delivers education to train the prospective teachers. It is also the mother of all professions. Like all other professions, globalization is also affecting teacher education. Therefore there is a global paradigm shift in teacher education. The main purpose of this study was to explore the paradigm shift in teacher education which has revolutionized teaching learning process at school level. The teacher education programs of five public universities of Pakistan where focused to fulfill the objectives of the study. The study was quantitative as well as qualitative in nature. Information regarding shift paradigm in teacher education were gathered by conducting self administered surveys, document analysis and interviews. Sample of the study comprised of prospective teachers, working teachers and executives (directors and heads) total 100 prospective teachers, 50 working teachers and 20 executives were selected by using random sampling techniques, collected data was analyzed by implementing simple descriptive statistical techniques such as percentages. The main paradigm changes in teacher education in perception of the selected respondents were: increase in duration of teacher education programmes, standard based curriculum, balance in theory and practice, shift from teacher to student centered delivery system, quality assurance and shift in assessment procedures.
\end{abstract}

Keywords: Teacher Education, Globalization, Paradigm shift

\section{Introduction}

Globalization can be defined as a world-sweeping arrangement based upon: “...a creed of lower trade barriers; an end to exchange controls; freer movement of investment capital; and the displacement of public sector capital by the private sector." (Fontana 1999). Globalization, both as a phenomenon and as a creed, may influence and affect education. (Michelle, 2007).Globalization has brought a great effect to human life not only in economic issues, but also in political, social, and cultural issues. Its effect can be positive, or negative, depends on the quality of human resources. Indeed, human resources with low quality will fail, whether the only human resources with high quality standard will succeed in facing global challenges. To produce human resources with high quality, we need education with high quality too. In fact, according to the demand of facing global challenges, we need to improve the quality of education and develop education standards that contain global and international issues (Husain Jusuf, 2005).

According to the Guidelines for Global and International Studies Education (United States, 2002), among these issues are: what should all our students be expected to know and understand about the world? What skills and attitudes will our students need to confront future problems, which most assuredly will be global in scope? How are the global and international dimensions of learning being addressed by the new academic standards? What do scholars from the international relations discipline and experienced practitioners of global education believe students should know, and how can these insight best be incorporated into the existing standards? What global and international education guidelines are appropriate for pre-collegiate education? How schools implement these guidelines when confronted with so many other problems? 
The answers of the questions stated above present an array of diverse approaches, contents, skills, methods, and values. We need to develop a high quality education system in which every student can be provided access to the educational components that are essential to such system. According to The California Master Plan for Education (2003) among these components are as follows:

i. A qualified and inspiring teacher in the classroom

ii. A rigorous curriculum that will prepare all students for success in postsecondary education, work, and society.

iii. Current textbooks, technology, and instructional materials aligned with learning expectations.

iv. Adequate learning support services.

v. Qualified school or campus administrators, to maintain an educational culture that is inviting and safe, and that places a high value on student achievement and teaching excellence, and

vi. A physical learning environment that is safe, well equipped, and well maintained.

Jarvis and Holford (2005) hold that 'globalization' may positively influence education, since it may bring together different peoples, ideas and resources in a world-wide pool. The whole world is becoming a global society; media and cyber culture are becoming more widespread. This is providing new opportunities for research and interaction to people who previously had no access to major libraries or research institutions (Kellner 2005, 102). Technological tools and developments can be applied to good use, so as to serve the needs of students across the world. This position holds that with capital shifting into a knowledge-based economy, information and knowledge is fast becoming a high-priced new commodity. Knowledge has become a principal economic currency, and its rapid production and circulation have become a crucial input for economic performance. As to the role of teachers, contemporary teacher education, at best, tends to take a politically neutral direction and, as a consequence, it is limited in the ways it can equip teachers to understand how forces of globalization and Neo-Liberalism are not forces in their own right but connected to a wider system of exploitation. (Michelle, 2007).

According to Heil (2003), ‘ . . a key role for higher education institutions must be to graduate future teachers who think globally, have international experience, demonstrate foreign language competence, and are able to incorporate a global dimension into their teaching'.

The quality of education provided by the public sector in Pakistan has been poor due to low levels of teacher competence, lack of classroom-based support for teachers, poor quality of textbooks and learning materials, lack of systems to assess student-learning outcomes, uneven supervision, insufficient resources for critical teaching and learning materials, and weak sector governance and management (World Bank, "Third Punjab Education", 2006). Research indicates that teacher quality, and supportive school organization and management, significantly influence school improvement, and eventually pupil learning. Literature also suggests that the quality of a teacher is generally dependent on the quality of his/her education, training, and availability of post-training support (AKF, 1998).

For education to improve, all the teachers must have a global perspective, well prepared and provided with ongoing professional development and appropriate support. All teachers have to fulfill the standards of professional teacher. For this purpose, we need standards with international scope and know how to achieve these standards. The Competency-Based Curriculum represents an approach to instruction which emphasizes the application of knowledge in a manner which may be observed or measured. Competency-Based Curriculum guides focus on a comprehensive view of each course of study which is delineated into its essential components, a listing of the most important objectives to be mastered, and the competencies which every student should be able to demonstrate after instruction is completed. Competency-Based lessons require students to engage in activities designed to apply learning with an increased emphasis on higher order thinking skills. Students are evaluated not only on knowledge, but primarily on their ability to perform tasks associated with the knowledge acquired. The technology base is more concerned with giving a broad overview of the various technologies available, the functions they can perform and their advantages and constraints. In addition to studying the current capability of a technology, students should be given some insight into how that technology might develop in the future.

According to Cradler (2002), '. . . a growing challenge in education is establishing and implementing strategies to develop the skills and knowledge necessary for teachers to effectively use technology as instructional tools. The extent to which teachers are prepared to infuse technology into curricula and instruction is a major contextual factor'.

Research findings cried out by Abbot \& Faris (2000) indicate that effective strategies for preparing new teachers to use and integrate technology are: demonstrate infusion of technology into instructional practices, require that college faculty use technology in their courses as learning and teaching tool. Preserves elementary teachers learn technology 
integration strategies by working with and observing practicing teachers and students while they use technology. In order to integrate new technologies into the curriculum, teachers will have to select appropriate software, construct new lesson plans, resolve a number of logistical problems, and develop appropriate methods of assessing student work.

In order to ensure the high quality of education, the Government should select the teacher based on professional competency and professional responsibility. In this case, it should be taken into account that not all of the teachers who have professional competency have also professional responsibility. According to Sonoma State University Academic Sonate (2003), ' . . . the responsibilities of the teachers fall into five main areas: (1) to their subject; (2) to their students; (3) to the institution of which s/he is a part; (4) to their profession; and (5) to the community at large'. The greatest problem in teaching is how to create, sustain, and motivate good teachers throughout their careers. Recruiting and preparing high quality teachers must remain a priority for policymaker.

In education, the changes brought on by globalization have been manifested through various channels and mechanisms as reforms of structures, modes of financing, administration and curriculum. The global requirements identified for education include promoting life-long education; re-emphasizing the quality of pupil's experience; reorganizing subjects into key learning areas so as to develop a broad knowledge-base among pupils as well as the ability to think critically and innovate and fostering of global awareness and outlook, and rising levels of professionalism among teachers (Law, 2004)

Teacher education policy in Pakistan since the early 1998 can be seen as moving from evolutionary to technocratic modernization as successive governments tried to make the system more efficient and cost effective at the same time as attempting to solve such problems as pupil drop out and the low levels of achievement associated with urban schools. However, with its priority of greater control, technocratic modernization has created new problems such as teacher demoralization and a fall in recruitment, especially in shortage subject areas such as physics and technology. In the 1980s teacher education curricula in the Pakistan were dominated by the educational disciplines, especially philosophy, psychology and sociology. The assumption was that these disciplines formed: a key part of the content of what a professional teacher needed to know; the basis on which teachers could continue their studies for higher degrees.

During the past 10 years, reforming teacher education has become acutely politicized. This action was part of a systemic reform to articulate and align high standards for teachers and students. Teachers still came back from teaching practice with problems they could not solve. With their focus on 'problems', the university-based courses tended to confirm a 'social pathology' view of schooling; student teachers learned that schools failed either because pupils lacked motivation or ability or because they had "bad" teachers. Though student teachers experienced the problems of school failure as classroom-based, a teacher education curriculum that treats the problems as if their origins lie solely within the classroom will inevitably be inadequate. The new problem-based curricula denied students access to concepts which, by linking their practical experience to the wider context which shaped it, might have helped them improve.

For many years, there has been a consensus among teacher trainers that teacher training should include the development of both a knowledge base and skills in the instruction. The knowledge base includes emphasis on such areas as teaching theory, pedagogical methodology, child development, educational research, and subject content. The skill development part of the curriculum consists in practice, including early field experience and student teaching experiences where students must put into practice the knowledge they have gained through their course work. Both these elements were totally neglected in the curriculum of the education faculties. A close analysis shows that it lacked coherence and that the purpose of many courses is outmoded and hazy. There is also a lack of empirical data on the impact of the courses (Altan, 1998).

A flattened sense of the nature of teaching, as essentially a technical/rational domain, is not adequate. In addition to being aware of the actual complexities of classroom processes and student activities, as well as how they can be organized, prospective teachers must develop a larger, theoretical and normative framework that allows the development of a theory of education as well as a theory of teaching. However, the new teacher education programmes lack of all three competencies. Moreover, a national uniformed education for teacher education and the creation of a corollary culture for teacher education institutions undermines the development of alternative forms of teacher education, and novel approaches to curriculum development. The articulation of distinctive, fundamentally different approaches to teacher education might have not only different emphases than standards-driven programmes, but qualitatively different purposes and orientations

The current education system in Pakistan does not adequately support teachers or raise teacher quality to the levels needed to produce better students. Research shows that teachers need intensive training and continuous support to 
change their teaching practices in line with updated curriculum and learning expectations. Initial teacher education, in particular, would need to be redesigned to support the new expectations and requirements of teachers. The global and the European challenge is to create a stronger education system which produces higher skills among graduates who can function in an increasingly complex and competitive labor market teaching and the preparation of teachers is again being positioned as something like a science, now to be generated by an adherence to content and developmental standards and evaluation practices that guarantee results, and are underwritten by accreditation agencies such as the National Commission Teacher Education. Powerful institutions and groups, buttressed by fears about our economic and social futures, support this direction for teacher education. Among the most disheartening of the emerging results of this direction is a narrowing of what counts as quality and accountability in teacher education, and an equally problematic perspective concerning the means that will accomplish the ends being promoted. It was hoped that these reforms would guarantee particular classroom outcomes related to what is termed "learning".

In the pre-service program, instruction in the interpretive, normative, and critical perspectives on education should reflect and serve the rationale and goals of the professional teacher preparation program. No particular organization or format is specified. Learning may be structured around aspects of the school-society relationship, issues in educational policy, or particular disciplines, e.g., the history, philosophy, and sociology of education. Field experiences designed and supervised in collaboration with educational practitioners are appropriate components of foundational studies when those experiences contribute to students' abilities to interpret and communicate the content and context of educational thought and practice. This change recognizes the importance of such areas of study as educational psychology, curriculum and instruction, educational administration, and pedagogical methods within professional teacher preparation programs. However, instruction in these areas is not an acceptable substitute for humanistic and social foundational studies. A persistent issue that has plagued teacher education is the disconnect between theory and practice. The theory-practice gap was identified as a serious concern by all Alliance members (Cho, 2008; Farrington, 2008; Gambier et al., 2008; Husbands, 2008; Rasmussen, 2008). Critics of university based teacher education question the degree to which initial teacher education courses actually prepare teachers for classroom teaching. Some argue that more credit hours should be spent on ensuring mastery of content knowledge and less in pedagogy, while others assert that the teacher candidates will recognize the value of education studies later in their teaching careers; on the latter point there is little evidence to suggest that this is actually the case. There are also calls to make the practicum more effective and for schools to make more diverse and meaningful learning opportunities available to trainees. As 21 st century educators, we are now in a position to argue otherwise. Bereiter and Scardamalia (2005) assert that the traditional forms of knowledge are no longer adequate as they are based on a "mental fi ling cabinet" model. They propose new conceptions based on enabling learners to construct knowledge by drawing on a range of information, thus enabling them to obtain greater depths of understanding which they can then apply to new situations. Such a mastery of knowledge or rich disciplinarily, is essential if learners are to be prepared for life's challenges in the 21 st century. This in turn has significant implications for teacher preparation.

Reforms in teacher education rely on global discourses that move from one country to another. Globalization does not, anyway, mean that national distinctions become erased or that everything becomes identical (Popkewitz, 2000). Today's world is changing fast both economically and socially. While global competition is not perfect is all ways, for example free trade has not yet equated to fair trade, competition for ideas has never been stronger. Education has been recognized as the basic means of promoting the skills of globalization (Marginson, 1998). The global economy has also contributed to trend towards educational globalization and cultural investments (Ertl, \& Phillips, 2006).

The paradigmatic shift requires that the objectives of the education policy would be to serve the interests of students and learners rather than of those who develop policy or implement programmes. This is a very fundamental shift as it implies changes in all the important parameters of education: what educational provision to offer; who benefits from educational provision; what pedagogy and teaching and learning methods to employ; and how the resource cost should be shared among the stakeholders? Accordingly, the researcher recognizes the need for reforms and makes recommendations for action in a wide range of areas, which are divided into two categories. First, there are system level reforms, which deal with issues such as the vision of the system, sector priorities and governance, and resources for the sector. The second set of reforms address problems that are specific to individual sub sectors of education, ranging from early childhood education to adult learning. There is an urgent need to recognize teachers' work as complex and demanding, and improvement in teacher quality requires a re-conceptualization of how we prepare a new generation of teachers. Teacher preparation programmes require continual innovation to develop a new generation of teachers who have the ability to promote "complex learning" in students. To explore such innovations and shift due to globalization, this study is conducted. 


\section{Objectives of the Study}

Following were the main objectives of the study:

i. To explore the global paradigm shift and changes in teacher education programmes of Pakistan, focusing on following aspects

a. Curriculum

b. Delivery system

c. Assessment procedures

ii. To explore the degree of revolutionization of teaching learning process in these paradigm shift and changes.

iii. To investigate the level of realization of millennium development goals through paradigm shifts and changes in teacher education.

\section{Research Questions of the Study}

i. What are the global paradigm shift and changes in teacher education programmes of Pakistan, focusing on following aspects?

d. Curriculum

e. Delivery system

\section{f. Assessment procedures}

ii. What is the degree of revolutionization of teaching learning process in these paradigm shifts and changes?

iii. What is the level of realization of millennium development goals through paradigm shifts and changes in teacher education?

\section{Methodology and Procedure}

The main purpose of this study was to explore the paradigm shift in teacher education which has revolutionized teaching learning process at school level. The teacher education programs of five public universities of Pakistan where focused to fulfill the objectives of the study. The study was quantitative as well as qualitative in nature. Information regarding shift paradigm in teacher education were gathered by conducting self administered surveys, document analysis and interviews. Questionnaire for survey was self developed comprised of 20 statement regarding paradigm shifts and changes in curriculum, delivery system and assessment procedures in teacher education progrmmes of Pakistan. This questionnaire was validated through experts' opinion. Sample of the study comprised of prospective teachers (B.ed level), working teachers and executives (directors and heads).Total 100 prospective teahers, 50 working teachers and 20 executives were selected by using random sampling techniques, collected data was analyzed by implementing simple descriptive statistical techniques such as mean and percentages.

\section{Results of the Questionnaire}

Table 1 shows that about $63 \%(33 \%+30 \%)$ prospective teachers under study agreed that globalization has brought paradigm shifts and changes in the curriculum of teacher education such as incorporation of global changes, international standards, extension of duration, balance in theory and practice, objectives of the curriculum and flexibility in teacher education curriculum. while only $27 \%(15 \%+12 \%)$ teachers didn't agree about these changes and near about $11 \%$ remained neutral.

Table 2 Shows that round about $74 \%(39 \%+35 \%)$ prospective teachers under study agreed that globalization has brought paradigm shifts and changes in the delivery system in teacher education such as shift in teacher centered delivery system to student centered delivery system, meeting needs and interests of students, students' participation, ICT integration and flexibility. While only $18 \%(10 \%+08 \%)$ teachers didn't agree about these changes and near about $10 \%$ remained neutral.

Table 3 Shows that round about $64 \%(34 \%+30 \%)$ prospective teachers under study agreed that globalization has brought paradigm shifts and changes in the delivery system in assessment procedures in teacher education such as adjustment of continuous assessment techniques, standardization of assessment criteria, comprehensive assessment techniques and HEC accreditation. While only $26 \%(15 \%+11 \%)$ teachers didn't agree about these changes and near about $10 \%$ remained neutral.

Table 4 shows that about $76 \%(39 \%+37 \%)$ prospective teachers under study agreed that globalization has brought paradigm shifts and changes in the curriculum of teacher education such as incorporation of global changes, international standards, extension of duration, balance in theory and practice, objectives of the curriculum and 
flexibility in teacher education curriculum. while only $23 \%(13 \%+09 \%)$ teachers didn't agree about these changes and near about $4 \%$ remained neutral.

Table 5 Shows that round about $80 \%(42 \%+38 \%)$ prospective teachers under study agreed that globalization has brought paradigm shifts and changes in the delivery system in teacher education such as shift in teacher centered delivery system to student centered delivery system, meeting needs and interests of students, students' participation, ICT integration and flexibility. While only $18 \%(10 \%+08 \%)$ teachers didn't agree about these changes and near about $3 \%$ remained neutral.

Table 6 Shows that round about $72 \%(37 \%+35 \%)$ prospective teachers under study agreed that globalization has brought paradigm shifts and changes in the delivery system in assessment procedures in teacher education such as adjustment of continuous assessment techniques, standardization of assessment criteria, comprehensive assessment techniques and HEC accreditation. While only $26 \%(15 \%+11 \%)$ teachers didn't agree about these changes and near about $02 \%$ remained neutral.

Table 7 shows that $70 \%$ of the respondents in this study agreed about the paradigm shifts and changes in the teacher education curriculum, while only $25 \%$ of the respondents disagreed about these changes in teacher education curriculum. $77 \%$ of the respondents in this study agreed about the paradigm shifts and changes in the teacher education delivery system, while only $18 \%$ of the respondents disagreed about these changes in teacher education delivery system. $68 \%$ of the respondents in this study agreed about the paradigm shifts and changes in the teacher education assessment procedures, while only $26 \%$ of the respondents disagreed about these changes in teacher education assessment procedures.

\section{Results of the Interviews}

It was observed through extensive interviews of executives of teacher education programmes, that almost all executives were agreed about paradigm shifts and changes in curriculum, delivery system and assessment procedures of teacher education programmes. They agreed that Global changes are being incorporated in the curriculum of teacher education, International and global standards of education are being met through the curriculum of teacher education, Duration of courses of teacher education programmes has been extended to meet the global challenges and trends, The curriculum of teacher education programmes meets all the standards of quality, There is a balance in theory and practice in teacher education programmes, The objectives of the curriculum of teacher education programmes are according to the social and societal needs of the students, The curriculum of teacher education programmes is flexible enough to adopt and accommodate the global paradigm shifts and changes, Millennium development goals of education are being realized through the curriculum of teacher education programmes, The delivery system in teacher education programmes is being shifted from teacher to student centered methods, The delivery system is interactive in order to fulfill the needs and interests of the students, Student's participation is encouraged through group discussion, ICT has been integrated in the delivery system, The professional standards are being incorporated in delivery system to meet the global paradigm shifts and changes in teacher education, The students are practically trained during teaching learning process, The faculty of teacher education programmes is being trained under HEC professional development programmes to accommodate the global changes, Assessment of students is done through continuous assessment techniques, Assessment criteria are being standardized according to the global changes, Comprehensive assessment and evaluation techniques are used to measure the professional abilities of the students, The standardized global assessment procedures are being incorporated by using both teacher and student assessment techniques and Teacher education programmes are being accredited by HEC to meet the international and global criteria of teacher education.

\section{Conclusions}

On the basis of empirical finding of the study, there are some points that can be used for concluding purpose of this research paper.

1 Global changes are being incorporated in the curriculum of teacher education.

2 International and global standards of education are being met through the curriculum of teacher education.

3 Duration of courses of teacher education programmes has been extended to meet the global challenges and trends.

4 The curriculum of teacher education programmes meets all the standards of quality.

5 There is a balance in theory and practice in teacher education programmes.

6 The objectives of the curriculum of teacher education programmes are according to the social and societal needs of the students. 
7 The curriculum of teacher education programmes is flexible enough to adopt and accommodate the global paradigm shifts and changes.

8 Millennium development goals of education are being realized through the curriculum of teacher education programmes.

9 The delivery system in teacher education programmes is being shifted from teacher to student centered methods.

10 The delivery system is interactive in order to fulfill the needs and interests of the students.

11 Student's participation is encouraged through group discussion.

12 ICT has been integrated in the delivery system.

13 The professional standards are being incorporated in delivery system to meet the global paradigm shifts and changes in teacher education.

14 The students are practically trained during teaching learning process

15 The faculty of teacher education programmes is being trained under HEC professional development programmes to accommodate the global changes

16 Assessment of students is done through continuous assessment techniques.

17 Assessment criteria are being standardized according to the global changes.

18 Comprehensive assessment and evaluation techniques are used to measure the professional abilities of the students.

19 The standardized global assessment procedures are being incorporated by using both teacher and student assessment techniques.

20 Teacher education programmes are being accredited by HEC to meet the international and global criteria of teacher education.

\section{Limitations of the Study}

As it happens with all empirical researches, this study is not beyond its limitations. Due to lack of time and financial resources the study had following limitations:

1 Data was collected from prospective teachers, faculty members and executives of public sector universities of Pakistan.

2 Teacher education programmes of only five universities were considered for the purpose of the study.

3 Prospective teachers of only B.ed level were selected.

\section{Suggestions and Recommendations}

Reform is required in all areas: pre-service training and standardization of qualifications; professional development; teacher remuneration, career progression and status; and governance and management of the teaching workforce. Governments shall take steps to ensure that teacher recruitment, professional development, promotions and postings are based on merit alone. In-service training shall cover a wide range of areas: pedagogy and pedagogical content knowledge; subject content knowledge; testing and assessment practices; multi-grade teaching, monitoring and evaluation; and programmes to cater to emerging needs like trainings in languages and ICT. Curriculum development shall be objectives driven and outcome based. It shall focus on learning outcomes rather than content. It shall closely reflect important social issues; provide more room for developing the capacity for self-directed learning, the spirit of inquiry, critical thinking, problem-solving and team-work. Use of Information Communication Technologies (ICTs) in Education shall be promoted in line with Ministry of Education's "National Information and Communication Technology Strategy for Education in Pakistan".

There shall be an ongoing feedback and evaluation mechanism so that a continuous improvement process is institutionalized. Feedback should flow from the primary providers of education to the curriculum development process with the full involvement of all intermediary players. Assessment systems are quality measures that cater to a number of requirements of the education system. These can be used to measure overall system efficiency as well as individual student performance for movement in the education system. Assessment system currently suffers from several deficiencies in promoting quality education.A comprehensive assessment design would provide feedback for improvements at all tiers starting from changes in the classroom to improvements in the national systems.

Provision of quality education requires a mechanism for internal and external evaluation of quality parameters. In 
this regards it is necessary to ensure that program and university accreditation mechanisms are instituted that are compatible with international best practices and provide complete transparency of operation leading to enhanced provision of quality education. Faculty training in pedagogical, communication and ICT skills is required at all levels to enhance the efficiency of teaching in higher education. For promoting quality in its teaching function, universities shall specialize in particular areas, rather than each university attempting to cover the whole range of programmes.A continuous professional development (CPD) programme shall be designed for College and university teachers. The CPD, among other things, shall include the practice of subject-wise refresher courses for college teachers; Provinces/Area education departments shall ensure training of teachers in pedagogical skills and educational administration.

\section{References}

Abbott, J. A., \& Faris, S. E. (2000). Integrating technology into pre-service literacy instruction: A survey of elementary education students' attitudes toward computers. Journal of Research on Computing in Education, 33(2), $149-161$

Aga Khan Foundation, Pakistan. (1998). Putting the Child First: Teacher Education for Quality Learning and School Improvement. Social Policy Forum. Pakistan-Canada Social Institutions Development Program.

Altan. (1998). A call for change and pedagogy: A critical analysis of teacher education in Turkey, European Journal of Education, Vol. 33 (4), 407-418

Cradler. (2002). Research Implications for Preparing Teachers to Use Technology. [Online] Available: http:/caret.iste.org/caretadm/ news.documents/ProfDef.pdf (02-06-2010)

Ertl, H., \& Phillips, D. (2006). Standardization in EU education and training policy: findings from a European research network. Comparative Education, Vol. 42 (1), 77-91. http://dx.doi.org/10.1080/03050060500515769

Fontana, M., Joekes, S., \& Masika, R. (1999). Global Trade Expansion and Liberalisation: Gender Issues and Impacts A Study Prepared for the Department for International Development (DFID) UK, Institute of Development Studies. University of Sussex.

Heil, J. D., \& McCarthy, J. (2003). International Education and Teacher Preparation in the US, for Presentation at the National Conference "Global Challenges and U.S. Higher Education: National Needs and Policy Implications", Duke University.

Jarvis, P., \& Holford, J. (2005). Editorial Globalization: A moral phenomenon. International Journal of Lifelong Education, Vol. 24(2), 97 - 98. http://dx.doi.org/10.1080/02601370500056185

Jusuf, H. (2005). Improving teacher quality, a keyword for improving education facing global challenges. The Turkish Online Journal of Educational Technology. ISSN: 1303-6521, Vol. 4 (1). Negeri Gorontalo-Indonesia.

Kellner, \& Douglas. (2005). Globalization, September 11, and the Restructuring of Education. In Critical Theories, Radical Pedagogies, and Global Conflicts. Eds. Fischman, Gustavo E., Peter McLaren, Heinz Sünker and Colin Lankshear. Lanham: Rowman \& Littlefield Publishers, Inc.,

Law, W. W. (2004). Educational reform in Hong-Kong and Taiwan. International Review of Education, Vol. 50(5-6), 497-524. http://dx.doi.org/10.1007/s11159-004-4637-4

Marginson, S. (1999). After globalization: Emerging politics of Education. Journal of education Policy, 14(1), 19-31. http://dx.doi.org/10.1080/026809399286477

Popkewitz, T. S. (2000). Educational Knowledge: Changing Relationships between State, Civil Society and the Educational Community. New York State University of New York Press.

Tonna, A. M. (2007). Journal for Critical Education Policy Studies, Volume 5, Number 1, ISSN 1740-2743.

World Bank. (2006). Program Document for a Proposed Credit to the Islamic Republic of Pakistan for a First North West Frontier Province Development Policy Credit. Report No. 35479-PK. 


\section{Questionnaire}

Name

Gender $(\mathrm{F} / \mathrm{M})$

Department

Institute

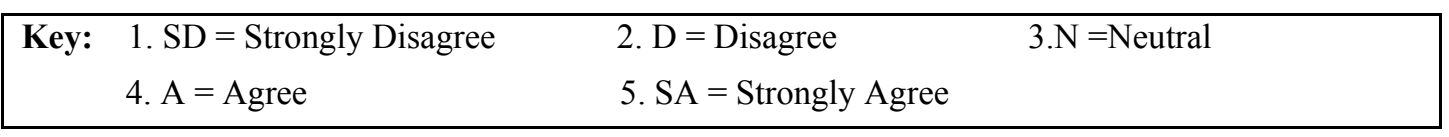

\section{INSTRUCTIONS}

Each statement has five options ranging from 1 to 5 . You have to tick one of the options for each statement according to your degree of agreement.

\begin{tabular}{|c|c|c|c|c|c|c|}
\hline $\begin{array}{l}\text { Sr. } \\
\text { No }\end{array}$ & Statements on curriculum & $\mathbf{S A}$ & A & $\mathbf{N}$ & D & $\begin{array}{l}\text { SD } \\
1\end{array}$ \\
\hline 1 & Global changes are being incorporated in the curriculum of teacher education. & & & & & \\
\hline 2 & $\begin{array}{l}\text { International and global standards of education are being met through the curriculum of teacher } \\
\text { education. }\end{array}$ & & & & & \\
\hline 3 & $\begin{array}{l}\text { Duration of courses of teacher education programmes has been extended to meet the global challenges } \\
\text { and trends. }\end{array}$ & & & & & \\
\hline 4 & The curriculum of teacher education programmes meets all the standars of quality. & & & & & \\
\hline 5 & There is a balance in theory and practice in teacher education programmes. & & & & & \\
\hline 6 & $\begin{array}{l}\text { The objectives of the curriculum of teacher education programmes are according to the social and } \\
\text { societal needs of the students. }\end{array}$ & & & & & \\
\hline 7 & $\begin{array}{l}\text { The curriculum of teacher education programmes is flexible enough to adopt and accommodate the } \\
\text { global paradigm shifts and changes. }\end{array}$ & & & & & \\
\hline \multirow[t]{2}{*}{8} & $\begin{array}{l}\text { Millennium development goals of education are being realized through the curriculum of teacher } \\
\text { education programmes. }\end{array}$ & & & & & \\
\hline & Statements on Delivery System & SD & D & $\mathbf{N}$ & A & $\begin{array}{l}\text { SA } \\
5\end{array}$ \\
\hline 9 & $\begin{array}{l}\text { The delivery system in teacher education programmes is being shifted from teacher to student centered } \\
\text { methods. }\end{array}$ & & & & & \\
\hline 10 & The delivery system is interactive in order to fulfill the needs and interests of the students. & & & & & \\
\hline 11 & Student's participation is encouraged through group discussion. & & & & & \\
\hline 12 & ICT has been integrated in the delivery system. & & & & & \\
\hline 13 & $\begin{array}{l}\text { The professional standards are being incorporated in delivery system to meet the global paradigm shifts } \\
\text { and changes in teacher education. }\end{array}$ & & & & & \\
\hline 14 & The students are practically trained during teaching learning process. & & & & & \\
\hline \multirow[t]{2}{*}{15} & $\begin{array}{l}\text { The faculty of teacher education programmes is being trained under HEC professional development } \\
\text { programmes to accommodate the global changes. }\end{array}$ & & & & & \\
\hline & Statements on Assessment Procedure & SD & $\begin{array}{l}\mathbf{D} \\
\mathbf{2}\end{array}$ & $\mathbf{N}$ & A & $\begin{array}{l}\text { SA } \\
5\end{array}$ \\
\hline 16 & Assessment of students is done through continuous assessment techniques. & & & & & \\
\hline 17 & Assessment criteria are being standardized according to the global changes. & & & & & \\
\hline 18 & $\begin{array}{l}\text { Comprehensive assessment and evaluation techniques are used to measure the professional abilities of the } \\
\text { students. }\end{array}$ & & & & & \\
\hline 19 & $\begin{array}{l}\text { The standardized global assessment procedures are being incorporated by using both teacher and student } \\
\text { assessment techniques. }\end{array}$ & & & & & \\
\hline 20 & $\begin{array}{l}\text { Teacher education programmes are being accredited by HEC to meet the international and global criteria } \\
\text { of teacher education. }\end{array}$ & & & & & \\
\hline
\end{tabular}


Table 1. Perception of prospective teachers regarding paradigm shifts in curriculum of teacher education.

\begin{tabular}{|c|c|c|c|c|c|c|}
\hline Item no & SA & A & $\mathbf{N}$ & D & SD & Total \\
\hline 1 & $\begin{array}{c}35 \\
(35 \%)\end{array}$ & $\begin{array}{c}25 \\
(25 \%)\end{array}$ & $\begin{array}{c}10 \\
(10 \%)\end{array}$ & $\begin{array}{c}20 \\
(20 \%)\end{array}$ & $\begin{array}{c}10 \\
(10 \%)\end{array}$ & $100(100 \%)$ \\
\hline 2 & $\begin{array}{c}30 \\
(30 \%)\end{array}$ & $\begin{array}{c}35 \\
(35 \%)\end{array}$ & $\begin{array}{c}15 \\
(15 \%)\end{array}$ & $\begin{array}{c}10 \\
(10 \%)\end{array}$ & $\begin{array}{c}10 \\
(10 \%)\end{array}$ & $100(100 \%)$ \\
\hline 3 & $\begin{array}{c}40 \\
(40 \%)\end{array}$ & $\begin{array}{c}35 \\
(35 \%)\end{array}$ & $\begin{array}{c}05 \\
(05 \%)\end{array}$ & $\begin{array}{c}10 \\
(10 \%)\end{array}$ & $\begin{array}{c}10 \\
(10 \%)\end{array}$ & $100(100 \%)$ \\
\hline 4 & $\begin{array}{c}45 \\
(45 \%)\end{array}$ & $\begin{array}{c}36 \\
(36 \%)\end{array}$ & $\begin{array}{c}04 \\
(04 \%)\end{array}$ & $\begin{array}{c}08 \\
(08 \%)\end{array}$ & $\begin{array}{c}07 \\
(07 \%)\end{array}$ & $100(100 \%)$ \\
\hline 5 & $\begin{array}{c}25 \\
(25 \%)\end{array}$ & $\begin{array}{c}25 \\
(25 \%)\end{array}$ & $\begin{array}{c}15 \\
(15 \%)\end{array}$ & $\begin{array}{c}20 \\
(20 \%)\end{array}$ & $\begin{array}{c}15 \\
(15 \%)\end{array}$ & $100(100 \%)$ \\
\hline 6 & $\begin{array}{c}27 \\
(27 \%)\end{array}$ & $\begin{array}{c}23 \\
(23 \%)\end{array}$ & $\begin{array}{c}15 \\
(15 \%)\end{array}$ & $\begin{array}{c}15 \\
(15 \%)\end{array}$ & $\begin{array}{c}20 \\
(20 \%)\end{array}$ & $100(100 \%)$ \\
\hline 7 & $\begin{array}{c}25 \\
(25 \%)\end{array}$ & $\begin{array}{c}27 \\
(27 \%)\end{array}$ & $\begin{array}{c}18 \\
(18 \%)\end{array}$ & $\begin{array}{c}20 \\
(20 \%)\end{array}$ & $\begin{array}{c}10 \\
(10 \%)\end{array}$ & $100(100 \%)$ \\
\hline 8 & $\begin{array}{c}38 \\
(38 \%)\end{array}$ & $\begin{array}{c}32 \\
(32 \%)\end{array}$ & $\begin{array}{c}05 \\
(05 \%)\end{array}$ & $\begin{array}{c}12 \\
(12 \%)\end{array}$ & $\begin{array}{c}13 \\
(13 \%)\end{array}$ & $100(100 \%)$ \\
\hline $\begin{array}{c}\text { Overall } \\
\text { Average \%age }\end{array}$ & $33 \%$ & $30 \%$ & $11 \%$ & $15 \%$ & $12 \%$ & $100(100 \%)$ \\
\hline
\end{tabular}

Table 2. Perception of prospective teachers regarding paradigm shifts in delivery system of teacher education.

\begin{tabular}{|c|c|c|c|c|c|c|}
\hline Item no & SA & $\mathbf{A}$ & $\mathbf{N}$ & D & SD & Total \\
\hline 9 & $\begin{array}{c}40 \\
(40 \%)\end{array}$ & $\begin{array}{c}35 \\
(35 \%)\end{array}$ & $\begin{array}{c}10 \\
(10 \%)\end{array}$ & $\begin{array}{c}08 \\
(08 \%)\end{array}$ & $\begin{array}{c}07 \\
(07 \%)\end{array}$ & $100(100 \%)$ \\
\hline 10 & $\begin{array}{c}38 \\
(38 \%)\end{array}$ & $\begin{array}{c}32 \\
(32 \%)\end{array}$ & $\begin{array}{c}12 \\
(12 \%)\end{array}$ & $\begin{array}{c}08 \\
(08 \%)\end{array}$ & $\begin{array}{c}10 \\
(10 \%)\end{array}$ & $100(100 \%)$ \\
\hline 11 & $\begin{array}{c}40 \\
(40 \%)\end{array}$ & $\begin{array}{c}30 \\
(30 \%)\end{array}$ & $\begin{array}{c}11 \\
(11 \%)\end{array}$ & $\begin{array}{c}11 \\
(11 \%)\end{array}$ & $\begin{array}{c}08 \\
(08 \%)\end{array}$ & $100(100 \%)$ \\
\hline 12 & $\begin{array}{c}41 \\
(41 \%)\end{array}$ & $\begin{array}{c}39 \\
(39 \%)\end{array}$ & $\begin{array}{c}07 \\
(07 \%)\end{array}$ & $\begin{array}{c}08 \\
(08 \%)\end{array}$ & $\begin{array}{c}05 \\
(05 \%)\end{array}$ & $100(100 \%)$ \\
\hline 13 & $\begin{array}{c}31 \\
(31 \%)\end{array}$ & $\begin{array}{c}35 \\
(35 \%)\end{array}$ & $\begin{array}{c}14 \\
(14 \%)\end{array}$ & $\begin{array}{c}18 \\
(18 \%)\end{array}$ & $\begin{array}{c}12 \\
(12 \%)\end{array}$ & $100(100 \%)$ \\
\hline 14 & $\begin{array}{c}44 \\
(44 \%)\end{array}$ & $\begin{array}{c}40 \\
(40 \%)\end{array}$ & $\begin{array}{c}06 \\
(06 \%)\end{array}$ & $\begin{array}{c}06 \\
(06 \%)\end{array}$ & $\begin{array}{c}04 \\
(04 \%)\end{array}$ & $100(100 \%)$ \\
\hline 15 & $\begin{array}{c}38 \\
(38 \%)\end{array}$ & $\begin{array}{c}36 \\
(36 \%)\end{array}$ & $\begin{array}{c}08 \\
(08 \%)\end{array}$ & $\begin{array}{c}10 \\
(10 \%)\end{array}$ & $\begin{array}{c}08 \\
(08 \%)\end{array}$ & $100(100 \%)$ \\
\hline $\begin{array}{c}\text { Overall } \\
\text { Average \%age }\end{array}$ & $39 \%$ & $35 \%$ & $10 \%$ & $10 \%$ & $08 \%$ & $100(100 \%)$ \\
\hline
\end{tabular}


Table 3. Perception of prospective teachers regarding paradigm shifts in assessment procedure of teacher education.

\begin{tabular}{|c|c|c|c|c|c|c|}
\hline Item no & $\mathbf{S A}$ & $\mathbf{A}$ & $\mathbf{N}$ & D & SD & Total \\
\hline 16 & $\begin{array}{c}35 \\
(35 \%)\end{array}$ & $\begin{array}{c}30 \\
(30 \%)\end{array}$ & $\begin{array}{c}14 \\
(14 \%)\end{array}$ & $\begin{array}{c}11 \\
(11 \%)\end{array}$ & $\begin{array}{c}10 \\
(10 \%)\end{array}$ & $100(100 \%)$ \\
\hline 17 & $\begin{array}{c}32 \\
(32 \%)\end{array}$ & $\begin{array}{c}25 \\
(25 \%)\end{array}$ & $\begin{array}{c}13 \\
(13 \%)\end{array}$ & $\begin{array}{c}18 \\
(18 \%)\end{array}$ & $\begin{array}{c}12 \\
(12 \%)\end{array}$ & $100(100 \%)$ \\
\hline 18 & $\begin{array}{c}27 \\
(27 \%)\end{array}$ & $\begin{array}{c}28 \\
(28 \%)\end{array}$ & $\begin{array}{c}16 \\
(16 \%)\end{array}$ & $\begin{array}{c}19 \\
(19 \%)\end{array}$ & $\begin{array}{c}10 \\
(10 \%)\end{array}$ & $100(100 \%)$ \\
\hline 19 & $\begin{array}{c}29 \\
(29 \%)\end{array}$ & $\begin{array}{c}25 \\
(25 \%)\end{array}$ & $\begin{array}{c}08 \\
(08 \%)\end{array}$ & $\begin{array}{c}20 \\
(20 \%)\end{array}$ & $\begin{array}{c}18 \\
(18 \%)\end{array}$ & $100(100 \%)$ \\
\hline 20 & $\begin{array}{c}45 \\
(45 \%)\end{array}$ & $\begin{array}{c}42 \\
(42 \%)\end{array}$ & $\begin{array}{c}03 \\
(03 \%)\end{array}$ & $\begin{array}{c}06 \\
(06 \%)\end{array}$ & $\begin{array}{c}04 \\
(04 \%)\end{array}$ & $100(100 \%)$ \\
\hline $\begin{array}{c}\text { Overall } \\
\text { Average } \% \text { age }\end{array}$ & $34 \%$ & $30 \%$ & $11 \%$ & $15 \%$ & $11 \%$ & $100(100 \%)$ \\
\hline
\end{tabular}

Table 4. Perception of working teachers (Education Faculty) regarding paradigm shifts in curriculum of teacher education.

\begin{tabular}{|c|c|c|c|c|c|c|}
\hline Item no & $\mathbf{S A}$ & $\mathbf{A}$ & $\mathbf{N}$ & D & SD & Total \\
\hline 1 & $\begin{array}{c}40 \\
(40 \%)\end{array}$ & $\begin{array}{c}36 \\
(36 \%)\end{array}$ & $\begin{array}{c}02 \\
(02 \%)\end{array}$ & $\begin{array}{c}12 \\
(12 \%)\end{array}$ & $\begin{array}{c}10 \\
(10 \%)\end{array}$ & $100(100 \%)$ \\
\hline 2 & $\begin{array}{c}42 \\
(42 \%)\end{array}$ & $\begin{array}{c}41 \\
(41 \%)\end{array}$ & $\begin{array}{c}03 \\
(03 \%)\end{array}$ & $\begin{array}{c}10 \\
(10 \%)\end{array}$ & $\begin{array}{c}04 \\
(04 \%)\end{array}$ & $100(100 \%)$ \\
\hline 3 & $\begin{array}{c}45 \\
(45 \%)\end{array}$ & $\begin{array}{c}42 \\
(42 \%)\end{array}$ & $\begin{array}{c}03 \\
(03 \%)\end{array}$ & $\begin{array}{c}06 \\
(06 \%)\end{array}$ & $\begin{array}{c}04 \\
(04 \%)\end{array}$ & $100(100 \%)$ \\
\hline 4 & $\begin{array}{c}35 \\
(35 \%)\end{array}$ & $\begin{array}{c}36 \\
(36 \%)\end{array}$ & $\begin{array}{c}04 \\
(04 \%)\end{array}$ & $\begin{array}{c}15 \\
(15 \%)\end{array}$ & $\begin{array}{c}10 \\
(10 \%)\end{array}$ & $100(100 \%)$ \\
\hline 5 & $\begin{array}{c}33 \\
(33 \%)\end{array}$ & $\begin{array}{c}32 \\
(32 \%)\end{array}$ & $\begin{array}{c}05 \\
(05 \%)\end{array}$ & $\begin{array}{c}20 \\
(20 \%)\end{array}$ & $\begin{array}{c}10 \\
(10 \%)\end{array}$ & $100(100 \%)$ \\
\hline 6 & $\begin{array}{c}39 \\
(39 \%)\end{array}$ & $\begin{array}{c}31 \\
(31 \%)\end{array}$ & $\begin{array}{c}04 \\
(04 \%)\end{array}$ & $\begin{array}{c}16 \\
(16 \%)\end{array}$ & $\begin{array}{c}10 \\
(10 \%)\end{array}$ & $100(100 \%)$ \\
\hline 7 & $\begin{array}{c}32 \\
(32 \%)\end{array}$ & $\begin{array}{c}36 \\
(36 \%)\end{array}$ & $\begin{array}{c}02 \\
(02 \%)\end{array}$ & $\begin{array}{c}16 \\
(16 \%)\end{array}$ & $\begin{array}{c}14 \\
(14 \%)\end{array}$ & $100(100 \%)$ \\
\hline 8 & $\begin{array}{c}42 \\
(42 \%)\end{array}$ & $\begin{array}{c}41 \\
(41 \%)\end{array}$ & $\begin{array}{c}03 \\
(03 \%)\end{array}$ & $\begin{array}{c}08 \\
(08 \%)\end{array}$ & $\begin{array}{c}06 \\
(06 \%)\end{array}$ & $100(100 \%)$ \\
\hline $\begin{array}{c}\text { Overall } \\
\text { Average \%age }\end{array}$ & $39 \%$ & $37 \%$ & $4 \%$ & $13 \%$ & $09 \%$ & $100(100 \%)$ \\
\hline
\end{tabular}


Table 5. Perception of working teachers (Education Faculty) regarding paradigm shifts in delivery system of teacher education.

\begin{tabular}{|c|c|c|c|c|c|c|}
\hline Item no & SA & $\mathbf{A}$ & $\mathbf{N}$ & $\mathbf{D}$ & SD & Total \\
\hline $\mathbf{9}$ & $45(45 \%)$ & $43(43 \%)$ & $01(01 \%)$ & $05(05 \%)$ & $06(06 \%)$ & $100(100 \%)$ \\
\hline $\mathbf{1 0}$ & $40(40 \%)$ & $35(35 \%)$ & $03(03 \%)$ & $12(12 \%)$ & $10(10 \%)$ & $100(100 \%)$ \\
\hline $\mathbf{1 1}$ & $46(46 \%)$ & $42(42 \%)$ & $02(02 \%)$ & $06(06 \%)$ & $04(04 \%)$ & $100(100 \%)$ \\
\hline $\mathbf{1 2}$ & $44(44 \%)$ & $41(41 \%)$ & $05(05 \%)$ & $07(07 \%)$ & $03(03 \%)$ & $100(100 \%)$ \\
\hline $\mathbf{1 3}$ & $37(37 \%)$ & $33(33 \%)$ & $03(03 \%)$ & $15(15 \%)$ & $12(12 \%)$ & $100(100 \%)$ \\
\hline $\mathbf{1 4}$ & $40(40 \%)$ & $30(30 \%)$ & $06(06 \%)$ & $14(14 \%)$ & $10(10 \%)$ & $100(100 \%)$ \\
\hline $\mathbf{1 5}$ & $42(42 \%)$ & $41(41 \%)$ & $02(02 \%)$ & $08(08 \%)$ & $07(07 \%)$ & $100(100 \%)$ \\
\hline $\begin{array}{c}\text { Overall } \\
\text { Average \%age }\end{array}$ & $\mathbf{4 2 \%}$ & $\mathbf{3 8 \%}$ & $\mathbf{3 \%}$ & $\mathbf{1 0 \%}$ & $\mathbf{0 8 \%}$ & $\mathbf{1 0 0}(\mathbf{1 0 0} \%)$ \\
\hline
\end{tabular}

Table 6. Perception of working teachers (Education Faculty) regarding paradigm shifts in assessment procedure of teacher education.

\begin{tabular}{|c|c|c|c|c|c|c|}
\hline Item no & SA & A & N & D & SD & Total \\
\hline $\mathbf{1 6}$ & $38(38 \%)$ & $36(36 \%)$ & $02(02 \%)$ & $12(12 \%)$ & $12(12 \%)$ & $100(100 \%)$ \\
\hline $\mathbf{1 7}$ & $37(37 \%)$ & $35(35 \%)$ & $03(03 \%)$ & $13(13 \%)$ & $12(12 \%)$ & $100(100 \%)$ \\
\hline $\mathbf{1 8}$ & $31(31 \%)$ & $30(30 \%)$ & $02(02 \%)$ & $20(20 \%)$ & $17(17 \%)$ & $100(100 \%)$ \\
\hline $\mathbf{1 9}$ & $34(34 \%)$ & $32(32 \%)$ & $04(04 \%)$ & $15(15 \%)$ & $15(15 \%)$ & $100(100 \%)$ \\
\hline $\mathbf{2 0}$ & $47(47 \%)$ & $42(42 \%)$ & $01(01 \%)$ & $04(04 \%)$ & $06(06 \%)$ & $100(100 \%)$ \\
\hline $\begin{array}{c}\text { Overall } \\
\text { Average \%age }\end{array}$ & $\mathbf{3 7 \%}$ & $\mathbf{3 5 \%}$ & $\mathbf{0 2 \%}$ & $\mathbf{1 3 \%}$ & $\mathbf{1 3 \%}$ & $\mathbf{1 0 0}(\mathbf{1 0 0 \% )}$ \\
\hline
\end{tabular}

Table 7. Perception of prospective and working teachers (Education Faculty) regarding paradigm shifts in teacher education.

\begin{tabular}{|c|c|c|c|c|c|c|}
\hline $\begin{array}{c}\text { Aspects of } \\
\text { teacher } \\
\text { education }\end{array}$ & $\begin{array}{c}\text { Prospective } \\
\text { teachers on } \\
\text { Agreement } \\
\text { side }\end{array}$ & $\begin{array}{c}\text { Working } \\
\text { teachers on } \\
\text { Agreement } \\
\text { side }\end{array}$ & $\begin{array}{c}\text { Average } \\
\text { respondents on } \\
\text { agreement side }\end{array}$ & $\begin{array}{c}\text { Prospective } \\
\text { teachers on } \\
\text { Disagreement } \\
\text { side }\end{array}$ & $\begin{array}{c}\text { Working } \\
\text { teachers on } \\
\text { Disagreement } \\
\text { side }\end{array}$ & $\begin{array}{c}\text { Average } \\
\text { respondents on } \\
\text { disagreement } \\
\text { side }\end{array}$ \\
\hline CURRICULUM & $63 \%$ & $76 \%$ & $(63+76) / 2=70 \%$ & $27 \%$ & $23 \%$ & $(27+23) / 2=25 \%$ \\
\hline $\begin{array}{c}\text { DELIVERY } \\
\text { SYSTEM }\end{array}$ & $74 \%$ & $80 \%$ & $(74+80) / 2=77 \%$ & $18 \%$ & $18 \%$ & $(18+18) / 2=18 \%$ \\
\hline $\begin{array}{c}\text { ASSESSMENT } \\
\text { PROCEDURES }\end{array}$ & $64 \%$ & $72 \%$ & $(64+72) / 2=68 \%$ & $26 \%$ & $26 \%$ & $(26+26) / 2=26 \%$ \\
\hline
\end{tabular}

